DOI: http://doi.org/10.21698/simi.2017.0006

\title{
LABORATORY STUDIES ON ACCIDENTAL POLLUTION AND SOIL REMEDIATION TECHNIQUES
}

Maria Popa, Loredana Irena Negoita, Emilia Elena Oprescu, Sinziana Radulescu

University of Petroleum - Gas of Ploiesti, 39 Bucuresti Blvd, 100680, Ploiesti, Romania, mariapopa2007@gmail.com,irena.negoita@gmail.com,oprescuemilia@gmail.com, marasescusinziana@yahoo.com

\begin{abstract}
In this paper there are presented laboratory studies on the influence of additives in diesel fuels on accidental pollution of the soil. The additive used in the experiments was cyclohexanone ketal glycerol. The presence of hydroxyl groups in the structure of ketals of glycerol decreases the solubility of hydrocarbons. To solve this disadvantage and for improving other features, in order to use as additives/ components for classic fuel, the hydroxyl group of glycerol ketal methyl ethyl ketone was block by transesterification with methyl esters of monocarboxylic acids.

The results obtained were compared to the content of nutrients $(\mathrm{N}, \mathrm{P}, \mathrm{K})$ in the soil polluted with diesel fuel additives and diesel oil without additives.

It was performed the soils decontamination by applying the method of solvent extraction.

For ecological reconstruction there were used unpolluted soil samples, samples contaminated with diesel oil with and without additives and the resulting samples after the extraction with the solvents.
\end{abstract}

Keywords: extraction, ketal, nutrients, soil

\section{Introduction}

Diesel fuel is used in the diesel engines found in most buses, trains, freight trucks, boats, construction and farm vehicles, some cars and small trucks. Also, diesel fuel is used in diesel engine generators to generate electricity. The most common type of diesel fuel is a fractional distillate obtained from crude oil in the petroleum refineries, but in recent year's alternatives that are not derived from petroleum, such as biodiesel, biomass to liquid or gas to liquid diesel, are increasingly being developed and used.

Diesel oil derived from petroleum consists mainly of aliphatic hydrocarbons containing 8-28 carbon atoms with boiling points in the range of $130-370^{\circ} \mathrm{C}$. Also, it contains sulfur, nitrogen and oxygen in low concentrations and metals such as lead, calcium, copper, nickel, sodium, and uranium. In addition, the diesel fuel contains additives which provide fuel detergency, corrosion control, and stability enhancement. They contribute to protect against wear by improving fuel lubricity, controlling harmful deposit build-up, improve fuel economy and reduce emissions (Ribeiro et al. 2007).

Both during production, transport, storage and use of the diesel fuel there are numerous soil pollution accidents, and not only it, even air and water pollution. Once in the ground, diesel oil can produce chronic or acute effects in various plant species. Excepting the direct and indirect toxicity, it causes interference in the hydric relations of the plants. This interference and the anaerobic and hydrophobic conditions are the 


\section{INTERNATIONAL SYMPOSIUM "THE ENVIRONMENT AND THE INDUSTRY", SIMI 2017, PROCEEDINGS BOOK}

most important effect of diesel oil contaminated soil on seed germination and plant growth (Racine 1994; Bona et al. 2011). For over two decade, many researchers have reported a lower rate of germination in soil contaminated by petroleum or its derivatives (Adam \& Duncan 2002; Vavrek \& Campbell 2002; Méndez-Natera et al. 2004; Achuba 2006; Smith et al. 2006; Sharifi et al. 2007; Besalatpour et al. 2008; Korade \& Fulekar 2009; Njoku et al. 2009; Popa et al. 2010; Bona et al. 2011; Luhach \& Chaudhry 2012; Cruz et al. 2013; Zarinkamar et al. 2013; Hawrot-Paw \& Bąkowska 2014; Rusin et al. 2015; Shuang et al. 2015; Popa \& Onutu 2016).

Oprescu (2013) has done research on the use of cyclohexanone ketal glycerol as additive for diesel fuels. It is reported that the hydroxyl groups in the structure of ketals of glycerol decreases the solubility of hydrocarbons. To solve this disadvantage and for improving other features, in order to use as additives / components for classic fuel, the hydroxyl group of glycerol ketal methyl ethyl ketone was block by transesterification with methyl esters of monocarboxylic acids.

The objective of this study was to research the effect of cyclohexanone ketal glycerol additive in diesel oil on the nutrients content $(\mathrm{N}, \mathrm{P}, \mathrm{K})$ of an accidentally polluted soil in laboratory. The polluted soil was decontaminated by solvent extraction method. For ecological reconstruction there were used the following soil samples: unpolluted, polluted with diesel oil with additives and polluted with diesel oil without additives. The results obtained shows the differences between the nutrients content in the soil polluted with diesel oil, with and without additives.

\section{Experimental}

Table 1 shows the characteristics of cyclohexanoneglycerol ketal. In a typical experiment the glycerol ketal was synthesized into a $250 \mathrm{ml}$ three-neck round-bottom flask equipped with a mechanical stirrer, thermometer and Dean-Stark apparatus. In the first step the flask was charged with glycerol and $\mathrm{SO}_{4}{ }^{2-} / \mathrm{SnO}_{2}$ catalyst and heated under reaction conditions for 10 minutes. After that, cyclohexanone and toluene were introduced.

Table 1. Characteristics of cyclohexanoneglycerol ketal

\begin{tabular}{cc}
\hline Parameters & Values \\
\hline Kinematic viscosity at $40{ }^{\circ} \mathrm{C}\left(\mathrm{mm}^{2} / \mathrm{s}\right)$ & 34.45 \\
Density $\left(\mathrm{g} / \mathrm{cm}^{3}\right)$ & 0.8459 \\
Pour point $\left({ }^{\circ} \mathrm{C}\right)$ & -35.0 \\
Flash point $\left({ }^{\circ} \mathrm{C}\right)$ & 117.2 \\
Boiling point $\left({ }^{\circ} \mathrm{C}\right)$ & 165 \\
\hline
\end{tabular}

The solvent was used to overcome the reaction equilibrium by forming a heterogeneous azeotropic system with water. The reaction mixture was heated to reflux. After the completion of reaction, the catalyst was filtered and the solvent and carbonyl compound in excess were removed by distillation

The GC/MS-MS analysis of cyclohexanone glycerol ketalindicates the obtaining of 2 isomers and a chromatographic purity over $99 \%$ (Figure 1). 


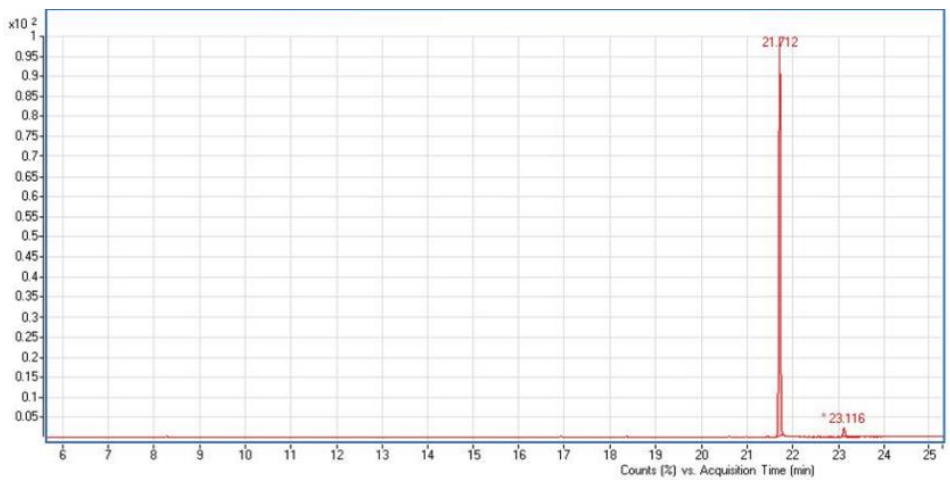

Figure 1. The GC/MS-MS analysis of cyclohexanone glycerol ketalindicates

The aim of the experimental determinations was the influence of the beforementioned product, used for diesel fuel additives, for accidental pollution with liquid petroleum products.

Forest soil was analysed, for which the following samples were prepared:

- sample $\mathrm{P}_{0}$ - witness sample, soil which is not polluted,

- sample $\mathrm{P}_{1}$ - soil and diesel fuel $(5,6 \%)$ - controlled pollution, undergone in the laboratory (this concentration was chosen because it is the closest to a real situation), - sample $\mathrm{P}_{2}$ - soil and equal quantities of diesel fuel and ketal.

These samples have gone through succesive extraction with solvents - petroleum ether and benzene.

The installation that was used, Soxhlet apparatus, is shown in Fig. 2. The results obtained from the extraction process with solvents of $\mathrm{P}_{0}, \mathrm{P}_{1}$ and $\mathrm{P}_{2}$ samples are presented in Table 2 .

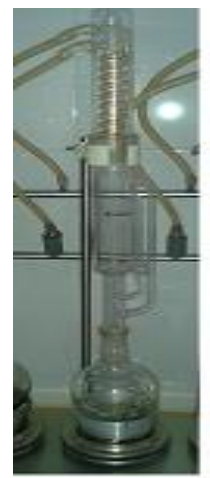

Figure 2. Soxhlet apparatus

The basic elements for a balanced soil, which have a decisive influence on the development of the plants $-\mathrm{N}, \mathrm{P}, \mathrm{K}$ (nitrogen, phosphorus, and potassium) are assimilated by the soil based on the $\mathrm{pH}$. The nutrients are chemical elements which are necessary for the survival of plants, animals and people and it is normal for them to exist in water soil and underground. However, when the amount of nutrients is too 


\section{INTERNATIONAL SYMPOSIUM "THE ENVIRONMENT AND THE INDUSTRY", SIMI 2017, PROCEEDINGS BOOK}

high, it is the case of nutrient pollution which is dangerous both for our health and the crops. The nutrients (nitrates, nitrites, ammonium, and phosphates) might be in excess in water as well, either by an incorrect fertilisation with chemical fertilizers or compost, or by not respecting important rules regarding the construction of stables and wells or by mismanaging the trash which ends up infiltrating in the soil and groundwater. Nutrient pollution of the soil has negative consequences upon crops and the environment. The nitrogen which is absorbed by the soil is converted, through various chemical reactions, in amino-acids that can be assimilated and which ensures that the leaves and stem can grow, the radicular system can develop and the plant gains the absorbing function. The deficiency of nitrogen in the plants nutrition leads to the leaves turning yellow and slowing or stopping their growth. Phosphorous, assimilated by the plant in the form of phosphoric acid or phosphoric anhydride intervenes in the functioning of the immune system, increasing the resistance of the plant against to crop conditions, atmospheric conditions and attacks of the pests and administration of insecticides. Potassium is converted in potassium hydroxide and assimilated by the plant in this form. It increases the capacity of the plant to store nutritive substances in organs such as rhizomes and tubers.

Table 2. Results obtained from the extraction process

\begin{tabular}{|c|c|c|c|c|}
\hline No. & Specified sine & $\begin{array}{c}\text { Clean soil } \\
\text { sample } \\
\mathrm{P}_{0} \\
\end{array}$ & $\begin{array}{c}\text { Polluted soil } \\
\text { sample } \\
P_{1} \\
\end{array}$ & $\begin{array}{c}\text { Polluted soil } \\
\text { sample } \\
\text { P }_{2}\end{array}$ \\
\hline 1. & $\begin{array}{l}\text { Quantityof } \\
\text { sample, } g\end{array}$ & 20,2 soil & $\begin{array}{l}\text { 20,2g soil } \\
1,2 \mathrm{~g} \text { Diesel } \\
\text { fuel }\end{array}$ & $\begin{array}{c}20,2 \mathrm{~g} \mathrm{soil} \\
1,2 \mathrm{~g} \text { Diesel } \\
\text { fuel } \\
1,2 \mathrm{~g} \text { ketal } \\
\end{array}$ \\
\hline \multirow[b]{2}{*}{2.} & \multirow[b]{2}{*}{$\begin{array}{l}\text { Quantityobtained } \\
\text { with petroleum } \\
\text { ether, }\end{array}$} & 0,2 & 1,4 & 1 \\
\hline & & & & \\
\hline & \multirow[b]{2}{*}{$\begin{array}{l}\text { Quantityobtained } \\
\text { with benzene, } g\end{array}$} & 0,05 & 0,05 & 0,45 \\
\hline & & & & \\
\hline 4. & $\begin{array}{l}\text { Total quantity } \\
\text { after extractiong }\end{array}$ & 0,25 & 1,45 & 1,45 \\
\hline
\end{tabular}

The deficiency of potassium in the plants' nutrition diminishes their growth and development.

Using the laboratory kit for analysing soils from Hanna Instruments was determined the nutrient content. This soil sample has average nitrogen content, low phosphorus content and low potassium content (determination based on turbidity determination). The nutrient content for sample $\mathrm{P}_{1}$ is shown in Fig. 3 and for sample $\mathrm{P}_{2}$ is shown in Fig. 4. 


\section{INTERNATIONAL SYMPOSIUM "THE ENVIRONMENT AND THE INDUSTRY", SIMI 2017, PROCEEDINGS BOOK}
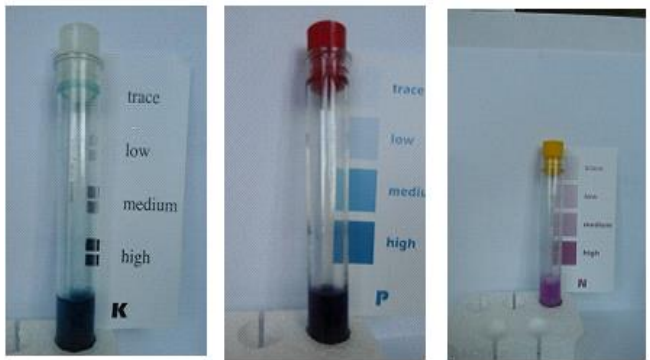

Figure 3. The nutrient content for sample $\mathrm{P}_{1}$
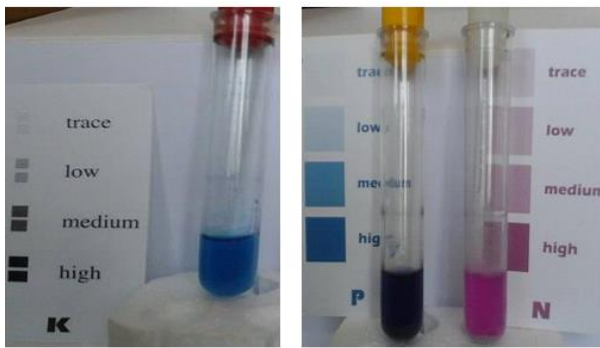

Figure 4. The nutrient content for sample $\mathrm{P}_{2}$

\section{Results and Discussion}

Regarding the results from the ecological reconstruction it is observed (in the table 3 ) that the germinating potential is not completely destroyed for the analyzed samples.

Table 3. Results from the ecological reconstruction

\begin{tabular}{|c|c|c|c|}
\hline & $\begin{array}{c}\text { Clean soil } \\
\text { sample } \\
\text { P0 }\end{array}$ & $\begin{array}{c}\text { Polluted soil } \\
\text { sample } \\
\text { P1 }\end{array}$ & $\begin{array}{c}\text { Polluted soil } \\
\text { sample } \\
\text { P2 }\end{array}$ \\
\hline & & & \\
$\begin{array}{c}\text { Ecobgical } \\
\text { reconstruction }\end{array}$ & & & \\
& & & \\
& & & \\
\hline
\end{tabular}

\section{Conclusions}

For sample $\mathrm{P}_{1}$ it is notices that there are extracted $1.45 \mathrm{~g}$ (of which 0.25 are the organic material that was extracted and the rest of 1.20 is the entire quantity of diesel fuel that polluted the soil). In this case, there is a depollution rate of $100 \%$. 


\section{INTERNATIONAL SYMPOSIUM "THE ENVIRONMENT AND THE INDUSTRY", SIMI 2017, PROCEEDINGS BOOK}

For sample $\mathrm{P}_{2}$, with the same quantity of material that was extracted, it is possible that this product, ketal, might not be extracted with these solvents which means that it will still exist in the structure of the soil. In a future paper we aim to analyse the products extracted in evaporating dish.

When it comes to the nutrient content, in the witness sample, there is a medium content of $\mathrm{N}$ and the content of $\mathrm{P}$ and $\mathrm{K}$ is reduced.

\section{References}

Achuba, FI 2006, 'The effect of sublethal concentrations of crude oil on the growth and metabolism of Cowpea (Vigna unguiculata) seedlings', Environmentalist, vol. 26, pp. 17-20.

Adam, G, \& Duncan, HJ 2002, 'Influence of Diesel Fuel on Seed Germination', Environmental Pollution, vol. 120, no. 2, pp. 363-370.

Besalatpour, A, Khoshgoftarmanesh, AH, Hajabbasi, MA \& Afyuni, M 2008, 'Germination and Growth of Selected Plants in a Petroleum Contaminated Calcareous Soil', Journal Soil and Sediment Contamination: An International Journal, vol. 17, no. 8, pp. 665-676.

Bona, C, de Rezende, IM, de Oliveira Santos, G \& de Souza, LA 2011, 'Effect of soil contaminated by diesel oil on the germination of seeds and the growth of Schinus terebinthifolius Raddi (Anacardiaceae) Seedlings', Brazilian Archives of Biology and Technology, vol. 54, no. 6, pp. 1379-1387.

Cruz, JM, Lopes, PRM, Montagnolli, RN, Tamada, IS, Silva, NMMG \& Bidoia, ED 2013, 'Phytotoxicity of Soil Contaminated with Petroleum Derivatives and Biodiesel', Ecotoxicology and Environmental Contamination - EEC, vol. 8, no. 1, pp. 49-54.

Hawrot-Paw, M \& Bąkowska, T 2014, 'Growth and development of selected plant species in the phytoremediation of diesel oil contaminated soil', Environment Protection Engineering, vol. 40, no. 4, pp. 5-13.

Korade, DL \& Fulekar, MH 2009, 'Effect of organic contaminants on seed germination of Lolium multiflorum in soil', Biology and Medicine, vol. 1, no. 1, pp. 28-34.

Luhach, J \& Chaudhry, S 2012, 'Effect of Diesel Fuel Contamination on Seed Germination and Growth of Four Agricultural Crops', Universal Journal of Environmental Research and Technology, vol. 2, no. 4, pp. 311-317.

Méndez-Natera, JR, Roque, C, Zapata, K \& OtaholaGómez, V 2004, 'Efecto de la concentración y tiempo de contaminación de un suelo por petróleo en la germinación de semillas de maíz (Zea mays L.) cv. Himeca 95', Revista UDO Agrícola, vol. 4, pp. 66-71.

Njoku, K.L, Akinola, MO \& Taiwo, BG 2009, 'Effect of gasoline diesel fuel mixture on the germination and the growth of Vigna unguiculata (Cowpea)', African Journal of Environmental Science and Technology, vol. 3, no. 12, pp. 466-471.

Oprescu, EE 2013 Glycerol valorification as additives/components for diesel fuels, $\mathrm{PhD}$ thesis, Petroleum-Gas University of Ploiesti, Ploiesti, Romania

Popa, M, Negoita, L, Radulescu, S 2010, 'Techniques for Remediation of Soils Contaminated with Liquid Petroleum Products for Ecological', Buletinul UPG, Seria Tehnica, vol. LXII, no.3A, p.70 


\section{INTERNATIONAL SYMPOSIUM "THE ENVIRONMENT AND THE INDUSTRY", SIMI 2017, PROCEEDINGS BOOK}

Popa, M \& Onutu, I 2016, 'Studies on the Seed Germination Changes after Thermal Decontamination of Crude Oil Polluted Soils', Agriculture and Agricultural Science Procedia, vol. 10, pp. 452-457.

Racine, CH 1994, 'Long-term recovery of vegetation on two experimental crude oil spills in interior Alaska black spruce taiga', Canadian Journal of Botany, vol. 72, no. 8, pp. 1171-1177.

Ribeiro, NM, Pinto, AC, Quintella, CM, da Rocha, GO, Teixeira, LSG, Guarieiro, LLN, do Carmo Rangel, M, Veloso, MCC, Rezende, MJC, da Cruz, RS, de Oliveira, AM, Torres, EA, \& de Andrade, JB 2007, 'The Role of Additives for Diesel and Diesel Blended (Ethanol or Biodiesel) Fuels: A Review', Energy \& Fuels, vol. 21, pp. 2433-2445.

Rusin, M, Gospodarek, J \& Nadgórska-Socha, A 2015, 'The Effect of PetroleumDerived Substances on the Growth and Chemical Composition of Vicia faba L.', Polish Journal of Environmental Studies, vol. 24, no. 5, pp. 2157-2166.

Sharifi, M, Sadeghi, Y \& Akbarpour, M 2007, 'Germination and growth of six plant species on contaminated soil with spent oil', International Journal of Environmental Science \& Technology, vol. 4, no. 4, pp. 463-470.

Shuang, S, Zhenfang, G \& Xiaolei, G 2015, 'The Effect of Bacteria on Seed Germination in Sorghum and Rape Under Cadmium and Petroleum Conditions', International Journal of Biotechnology for Wellness Industries, vol. 4, no. 4, pp. 123-127.

Smith, MJ, Flowers, TH, Duncan, HJ \& Alder, J 2006, 'Effects of polycyclic aromatic hydrocarbons on germination and subsequent growth of grasses and legumes in freshly contaminated soil and soil with aged PAHs residues', Environmental Pollution, vol. 141, pp. 519-525.

Vavrek, MC \& Campbell, WJ 2002, 'Contribution of seed banks to freshwater wetland vegetation recovery’, Louisiana Applied and Educational Oil Spill Research and Development Program, OSRADP. Technical Report Series, 0-12.

Zarinkamar, F, Reypour, F \& Soleimanpour, S 2013, 'Effect of Diesel Fuel Contaminated Soil on the Germination and the Growth of Festuca arundinacea', Research Journal of Chemical and Environmental Sciences, vol. 1, no. 2, pp. 37-41. 